RAGASSI, CF; ZUCOLOTTO, J; GOMES, LM; RIBEIRO, CSC; MADEIRA, NR; REIFSCHNEIDER, FJB. 2019. Productivity, quality of fruits and architecture of Jalapeño pepper at different planting densities. Horticultura Brasileira 37:331-337. DOI - http://dx.doi.org/10.1590/S0102-053620190312

\title{
Productivity, quality of fruits and architecture of Jalapeño pepper at different planting densities
}

\author{
Carlos Francisco Ragassi ${ }^{1} \mathbb{D}$; Juliana Zucolotto ${ }^{2} \mathbb{D}$; Lucas M Gomes ${ }^{3 \mathbb{D}}$; Cláudia SC Ribeiro ${ }^{1 \mathbb{D}}$; Nuno \\ Rodrigo Madeira 1무 Francisco José B Reifschneider ${ }^{4} \mathbb{D}$
}

'Embrapa Hortaliças, Brasília-DF, Brasil; carlos.ragassi@embrapa.br; claudia.ribeiro@embrapa.br; nuno.madeira@embrapa.br; ${ }^{2} E s c o l a$ Superior de Agricultura “Luiz de Queiroz” (ESALQ), Piracicaba-SP, Brasil; julianazucolotto@gmail.com; ${ }^{3}$ Universidade Federal de Goiás (UFG), Goiânia-GO, Brasil; lucasmatyasgomes@gmail.com; ${ }^{4}$ Embrapa Secretaria de Inteligência e Relações Estratégicas, Brasília-DF, Brasil; francisco.reifschneider@embrapa.br

\begin{abstract}
Mechanizing the harvest of Jalapeño pepper involves changes in the production system. Spacings between plants in rows (10 to 40 $\mathrm{cm} ; 60 \mathrm{~cm}$ fixed between rows) were evaluated in relation to plant architecture, productivity and fruit quality of cultivar BRS Sarakura during three years, in a randomized complete block design with five replicates. Productivity (41.9 to $78.8 \mathrm{tha}^{-1}$ ) and plant height (40.1 to $47.3 \mathrm{~cm})$ responded linearly to density; on the other hand, productivity per plant responded negatively $\left(0.48\right.$ to $\left.1.04 \mathrm{~kg} \mathrm{plant}^{-1}\right)$. The stem first bifurcation height was little influenced. Fruit chemical analyses were carried out in the second year of the experiment; spacing significantly influenced $\mathrm{pH}$ (5.36 to 4.84), total titratable acidity (TTA) (0.48 to $0.36 \%$ ) and total soluble solids (TSS)/TTA ratio (11.5 to 15.6 ); no influence on TSS $(5.65 \%)$ was noticed, though. The increase of plant population provided an increase in productivity without affecting fruit quality; the highest height of the first bifurcation achieved may not be enough to enable mechanized harvesting of the cultivar BRS Sarakura.
\end{abstract}

Keywords: Capsicum annuum, mechanized harvesting, crop management, processing.

\section{RESUMO}

Produtividade, qualidade de frutos e arquitetura de plantas de pimenta Jalapeño em diferentes adensamentos de plantio

Mecanizar a colheita de pimenta Jalapeño exige adequação do sistema de produção. Espaçamentos entre plantas na linha (10 a 40 $\mathrm{cm} ; 60 \mathrm{~cm}$ fixo entre linhas) foram avaliados quanto à arquitetura da planta, produtividade e qualidade de frutos da cultivar BRS Sarakura, durante três anos no delineamento blocos ao acaso, com cinco repetições. A produtividade de frutos $\left(41,9 \mathrm{a} \mathrm{78,8} \mathrm{t} \mathrm{ha}^{-1}\right)$ e a altura de planta $(40,1 \mathrm{a} 47,3 \mathrm{~cm})$ responderam de forma linear ao adensamento, ao passo que a produtividade por planta apresentou tendência oposta $\left(0,48\right.$ a $\left.1,04 \mathrm{~kg} \mathrm{planta}^{-1}\right)$. A altura da primeira bifurcação do caule foi pouco influenciada. Análises químicas dos frutos foram feitas no segundo ano de condução do experimento; o espaçamento influenciou significativamente $\mathrm{pH}(5,36$ a 4,84), acidez total titulável (ATT) $(0,48$ a $0,36 \%$ ) e relação sólidos solúveis totais $(\operatorname{SST}) /$ ATT $(11,5$ a 15,6$)$, porém não influenciou SST $(5,65 \%)$. O incremento da população de plantas proporcionou aumento na produtividade sem prejudicar a qualidade dos frutos; a maior altura da primeira bifurcação atingida pode não ser suficiente para possibilitar a colheita mecanizada da cultivar BRS Sarakura.

Palavras-chave: Capsicum annuum, colheita mecanizada, manejo cultural, processamento.

\section{Received on April 4, 2019; accepted on August 5, 2019}

$\mathrm{T}_{\mathrm{s}}$ he state of Goiás has, at least, five pepper sauce processing plants, located in the municipalities of Ouvidor/Catalão, Nerópolis, Goiânia and Abadiânia (Onoyama et al., 2011). Jalapeño pepper (Capsicum annuum var. annuum) stands out among several varietal groups of pepper grown for industrial purposes as these fruits are suitable for sauce processing due to its thick pulp and intense red color (Ribeiro, 2008; De Witt \& Bosland, 2009).

Approximately 50 ha are cultivated yearly using the Jalapeño pepper cultivar BRS Sarakura, obtained from a longterm partnership between the Brazilian Agricultural Research Corporation (Embrapa) and a large food industry, in Ouvidor-GO region, covering practically all the pepper production areas for industry in that region. This production corresponded to over $50 \%$ of pepper sauce produced in Brazil in 2015 (Reifschneider et al., 2016), last survey conducted.

The main requirements in the context of the cultivar BRS Sarakura development were high yield, resistance to diseases and uniformity of plants and fruits, besides high pungency. In that context, harvest was traditionally performed manually, so, the cultivar was developed with traits adapted to that production system (Embrapa, 2015).

The demand for raw material to produce pepper sauce is increasing; however, growing areas in Ouvidor-GO region are not increasing, especially due to harvest labor shortage, a problem that is getting worse as a result of demographic changes, from countryside 
to urban centers, predominant in the Country (Embrapa, 2014). From short to medium turn, this condition can make expansion of processing industries in the region, which are dependent on raw material supply, unfeasible.

The most logical alternative to labor shortage is the mechanization of harvest operation. However, effective technology adoption requires changes in production system to meet the minimum criteria required by mechanized operation. In particular, the low population density adopted in OuvidorGO region $\left(55,555\right.$ plants ha $^{-1}$ in spacing $60 \mathrm{~cm}$ between rows and $30 \mathrm{~cm}$ between plants) may be responsible for making the plant architecture excessively low, so that a significant part of the fruits cannot be harvested when the operation is mechanically performed. Preliminary estimates accounted for losses from 30 to $40 \%$ of fruits, which remain attached to the plants after use of the harvesting machine model Etgar Moses 1010 imported from Israel, the only machine available in the region. In order to compare, $20 \%$ is the maximum quantity for loss acceptable in mechanized harvest, according to studies carried out in New Mexico State, EUA(Paroissien \& Flynn, 2004). However, field experiments in Ouvidor-GO region using this machine demonstrated that $100 \%$ of the fruits whose insertion is located above 20 $\mathrm{cm}$ high in relation to the ground are actually harvested (Embrapa, 2015).

Denser planting in rows can influence plant height and height of the lowest fruit insertion, which may provide better plant suitability for mechanized harvest and, consequently, higher yield (Wall et al., 2003; Paroissien \& Flynn, 2004; Funk \& Walker, 2009; Uchanski \& Blalock, 2013; Walker \& Funk, 2014). Besides, higher density in spacing between plants in planting rows shows potential response to productive increase, especially under growing conditions in the dry season of Brazilian Planalto Central, where climatic conditions are not favorable for disease development, normally favored by populational density (Ribeiro, 2008). However, production and quality of fruits must be evaluated when spacing is changed: to avoid having productivity per area or quality of produced fruits impaired (Cavero et al., 2001; Paroissien \& Flynn, 2004; Akintoye et al., 2009).

This study was carried out to evaluate the influence of spacing between plants in planting lines in relation to productivity, plant architecture and fruit quality of Jalapeño pepper cultivar BRS Sarakura.

\section{MATERIAL AND METHODS}

\section{Obtaining seedling and experimental characterization}

Seedlings of cultivar BRS Sarakura were produced in expanded polystyrene trays with 128 cells, filled with 1:1 mixture of commercial substrates Vivato ${ }^{\circledR}$ and Bioplant ${ }^{\circledR}$. When the plants showed three or four true leaves (approximately 45 days after sowing), we transplanted them into the field (15 ${ }^{\circ} 55^{\prime} 57.31^{\prime \prime} \mathrm{S}, 48^{\circ} 8^{\prime} 11.36^{\prime \prime} \mathrm{O}, 997$ $\mathrm{m}$ altitude) in furrows spaced $60 \mathrm{~cm}$ among each other (minimum value required for using harvesting machine model Etgar Moses 1010). Soil in the experimental area was classified as Red Oxisol, showing, at planting time in the first experimental cycle, the following chemical properties in 0 to $20 \mathrm{~cm}$ layer: $\mathrm{pH}_{\text {(water) }}=5.6, \mathrm{pH}_{(\mathrm{CaCl} 2)}=5.1$, organic matter $=3.7 \%, \mathrm{P}_{(\text {Mehlich I) }}-83 \mathrm{mg} \mathrm{dm}^{-3}$, $\mathrm{K}_{\text {(Mehlich I) }}=294 \mathrm{mg} \mathrm{dm}^{-3}, \mathrm{~S}$ (monobasic calcium phosphate) $=26.4 \mathrm{mg} \mathrm{dm}^{-3}, \mathrm{Ca}=6.4 \mathrm{cmol}_{\mathrm{c}}$ $\mathrm{dm}^{-3}, \mathrm{Mg}=2.0 \mathrm{cmol}_{\mathrm{c}} \mathrm{dm}^{-3}, \mathrm{Al}=0.0 \mathrm{cmol}_{\mathrm{c}}^{\mathrm{c}}$ $\mathrm{dm}^{-3}, \mathrm{H}+\mathrm{Al}=6.8 \mathrm{cmol}_{\mathrm{c}} \mathrm{dm}^{-3}$, total cation exchange capacity at $\mathrm{pH} 7.0\left(\mathrm{CTC}_{\text {total }}\right)=$ $15.8 \mathrm{cmol} \mathrm{dm}^{-3}$, base saturation $(\mathrm{V})=$ $57 \%$, aluminum saturation $(\mathrm{m})=0 \%$, $\mathrm{B}_{\text {(hot water) }}=0.3 \mathrm{mg} \mathrm{dm}^{-3}, \mathrm{Zn}=18.6 \mathrm{mg} \mathrm{dm}^{-3}$, $\mathrm{Fe}=46.6 \mathrm{mg} \mathrm{dm}^{-3}, \mathrm{Mn}=33 \mathrm{mg} \mathrm{dm}^{-3}$ and $\mathrm{Cu}=3.5 \mathrm{mg} \mathrm{dm}^{-3}$. Soil was prepared, in the beginning of each evaluation year, using a harrow, a subsoiler and a leveling harrow. Finally, furrowing was performed with planting fertilization application, consisting of $30 \mathrm{~kg} \mathrm{ha}^{-1}$ $\mathrm{N}$ and $80 \mathrm{~kg} \mathrm{ha}^{-1} \mathrm{P}_{2} \mathrm{O}_{5}$, according to recommendation for the crop (Ribeiro, 2008). Top dressing fertilization was done using $120 \mathrm{~kg} \mathrm{ha}^{-1} \mathrm{~N}$ and $60 \mathrm{~kg}$ $\mathrm{ha}^{-1} \mathrm{~K}_{2} \mathrm{O}$, splitted in 6 times, also following the recommendation for the crop (Ribeiro, 2008). Transplanting, in each year, was performed on June 11, 2015; April 12, 2016, and April 11, 2017.

\section{Treatments and experimental} design

Treatments consisted of different spacings between plants in planting rows, $20 ; 25 ; 30 ; 35$ and $40 \mathrm{~cm}$ between plants in 2015,$15 ; 20 ; 25 ; 30 ; 35$ and $40 \mathrm{~cm}$ in 2016 and $10 ; 15 ; 20 ; 25 ; 30$ and $35 \mathrm{~cm}$ in 2017. Plant density/ha ranged from 41,666 to 83,333 in 2015, 41,666 to 111,111 in 2016 and 47,619 to 166,666 in 2017. Randomized complete block design, with 5 treatments and 5 replicates (2015) and 6 treatments and 5 replicates (2016 and 2017), was used. The plot consisted of five planting rows, 3.0 width and $10 \mathrm{~m}$ total length. The lateral end lines and plants $1.0 \mathrm{~m}$ from the beginning and end of each useful line were discarded, considering plot 8 -m central lines of the 3 central lines.

\section{Evaluated traits of plant and fruit}

Fruits were harvested at the same time when the field showed $70 \%$ of ripe fruits (considering ripe fruits the ones showing red color all over the surface), on September 30, 2015 (111 days after transplanting and 173 days after sowing), August 23, 2016 (143 days after transplanting and 188 after sowing) and August 29, 2017 (140 days after transplanting and 188 days after sowing). After harvest, fruit mass of 20 plants per plot (2015 and 2016) and ten plants per plot (2017) was quantified and a sample of approximately $1 \mathrm{~kg}$ was removed in order to obtain average fruit mass. A sample of 50 fruits per plot was used in order to establish the average fruit length. When the plants showed full fruiting, plant height and first bifurcation height were evaluated, both in relation to soil level.

\section{Fruit chemical analyses}

Ripe-fruit (completely red) chemical analyses were performed only in 2016, year when an industry demand to standardize these parameters was identified. Hydrogen potential $(\mathrm{pH})$, total soluble solids content (TSS) and total titratable acidity (TTA) were evaluated according to the methodology described by Mattos et al. (2007). 


\section{Statistical analysis}

A mixed-model joint analysis of variance (Moore \& Dixon, 2015) was used to evaluate plant heights and first bifurcation heights, productivity and length and mass of fruit. The completely randomized blocks used each year showed different number of plots, with some treatments in common (spacing between plants 20,25, 30 and $35 \mathrm{~cm}$ ), the correction of degrees of freedom being performed by the Satterthwaite method. We used Shapiro-Wilk test for residue normality and Levene test for homogeneity. Linear, quadratic and cubic regression effects were tested by orthogonal contrasts; when the values were significant, regression equations were established. Statistical significance was considered at 5\% error probability and the results were presented as averages \pm standard errors. The coefficient of determination $\left(\mathrm{R}^{2}\right)$ and the square root of the mean square error (RMSE) were also calculated. All analyses were performed using SAS University Edition (SAS Institute, 2012).

Regressions for variables related to fruit chemical analyses were established in relation to spacing between plants when data showed normal distribution and the $F$ test was significant $(p<0.05)$, with no need of correction of degrees of freedom, since these evaluations were performed only in 2016. These analyses were also carried out using SAS University Edition (SAS Institute, 2012).

\section{RESULTS AND DISCUSSION}

Spacing between plants influenced productivity/ha linearly (Figure 1A) and the maximum productivity was not achieved, showing that this productivity can be obtained with an even reduced spacing than the smallest spacing evaluated $(10 \mathrm{~cm}$ between plants in rows). Increase in productivity per area according to high plant density (lower-spaced plants) was expected up to a certain maximum value, above this value only smaller increases or even reduced productivity would be obtained (Cavero et al., 2001; Paroissien
\& Flynn, 2004; Akintoye et al., 2009), allowing to establish a spacing between plants in rows corresponding to the maximum productivity.

Fruit productivity per plant presented an inverse behavior in relation to productivity per area (Figure 1B), highlighting competition between plants (Abu \& Odo, 2017). The lower fruit load per plant without reduction of productivity per area is an interesting aspect for an effective mechanized harvesting, since it tends to reduce bending of plants and branches. Similar productive behavior in pepper $C$. annuum was obtained by Motsenbocker (1996) and Russo (2008), the first author working with 7.5 to $45-\mathrm{cm}$ spacing between plants $(121,100$ to 20,200 plants/ha in $1.1-\mathrm{m}$ spacing between lines) and the second author working with $8-48 \mathrm{~cm}$ spacing between plants $(137,000$ to 21,500 plants/ha). Recently, Aminifard et al. (2010) and Paulus et al. (2015) also verified that smaller spacing resulted in higher productivity of pepper fruits per area and lower productivity per plant. On the other hand, Paroissien \& Flynn (2004) verified an increase in fruit productivity/ ha due to high density of plants in only one of the six conducted experiments, reduction of productivity in two of the six conducted experiments and no effect on productivity in the other three experiments. Probably, the maximum potential of productivity in the system might have been achieved in the study carried out by Paroissien \& Flynn (2004), considering the used genotypes and environmental characteristics of the study, thus mitigating the effect of density.

The results in this study corroborate the results presented by Cavero et al. (2001), in which population density ranged between 13,000 and the maximum 533,333 plants/ha, showing a reduction in fruit productivity per plant and an increase of productivity per area

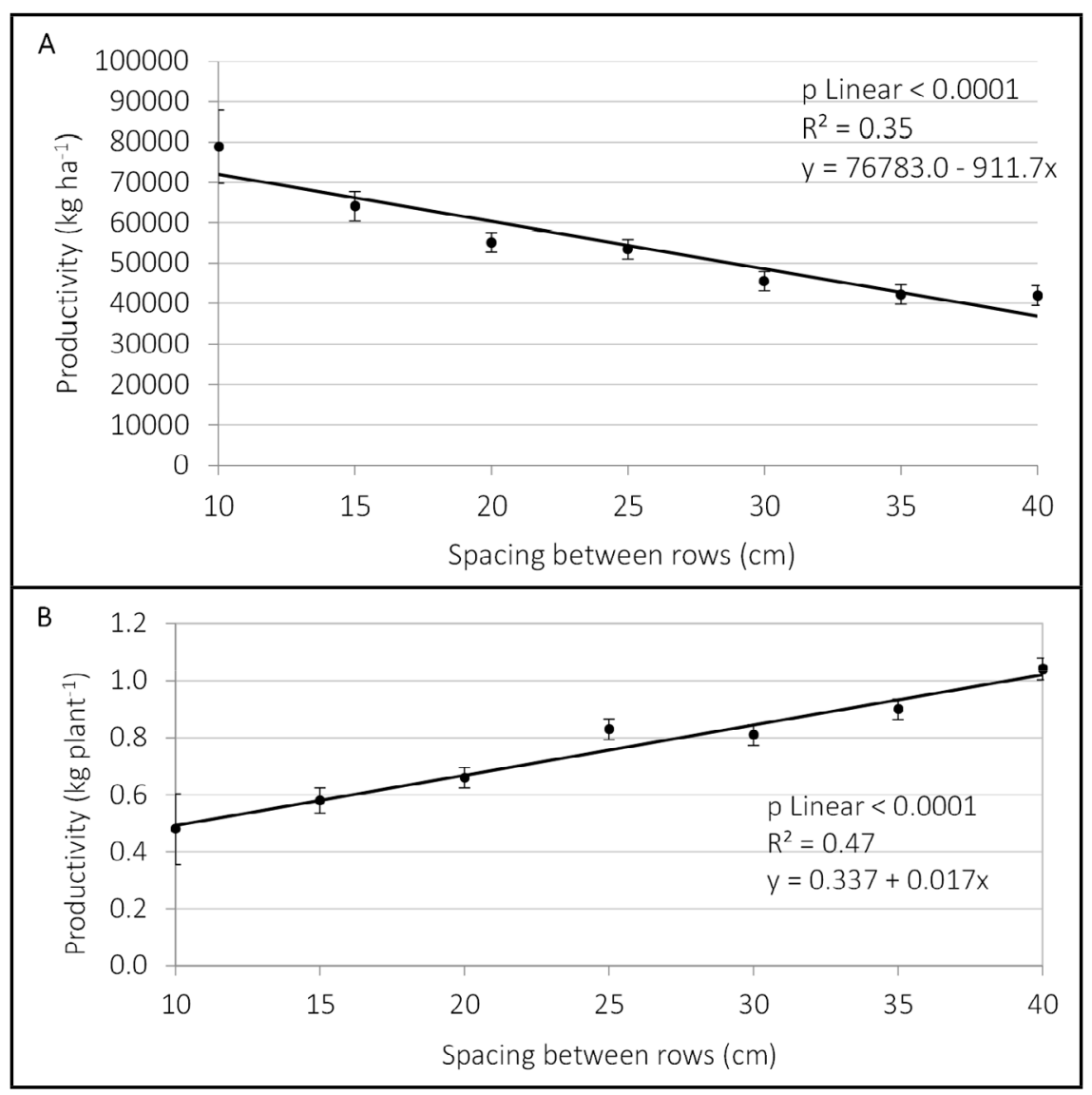

Figure 1. Productivity of Jalapeño pepper cultivar BRS Sarakura per area (A) and per plant (B) in relation to in-row plant spacing (average of three years, 2015, 2016 and 2017). Brasília, Embrapa Hortaliças, 2019. 
due to an increase in population. The density level in which the production per area was supposed to decrease was not achieved in the study carried out by Cavero et al. (2001), even with an extremely high population density, 533,333 plants/ha of paprika pepper (C. annuum). However, from 200,000 plants/ha, the authors observed quite small increases; due to this fact they recommended a population density limited to that value (Cavero et al., 2001).

We suggest here future studies on an economic analysis in order to find out if the increase provided by plant density in planting rows is higher than the increase in production cost caused by a greater number of seedlings/ha used and higher demand for labor work for transplant.

Individual fruit mass was not influenced by spacing, showing an average value of $38.9 \mathrm{~g}$ (range from 37.7 to $41.6 \mathrm{~g}$ considering average values for each studied spacing). Russo (2008) did not obtain any effect of plant spacing in rows $(8-48 \mathrm{~cm})$ on fruit mass produced even evaluating years and different times of cultivation. Nevertheless, Favela \& Sánchez (2003) verified an increase in the average fruit mass of Jalapeño pepper due to a reduction of spacing between plants in row from 55 $\mathrm{cm}\left(12.7 \mathrm{~g}_{\text {fruit }}{ }^{-1}\right)$ up to $10 \mathrm{~cm}(17.5$ $\mathrm{g}$ fruit $\left.^{-1}\right)$, regardless studied spacing between lines (from 50 to $110 \mathrm{~cm}$ ). On the other hand, Cavero et al. (2001) observed fruit mass reduction of paprika pepper due to an increase in planting density, considering that fruit mass values ranged very little, around $3.0 \mathrm{~g}$ of dry mass/fruit, in density extremes, 13,000 to 533,333 plants ha ${ }^{-1}$. Our results

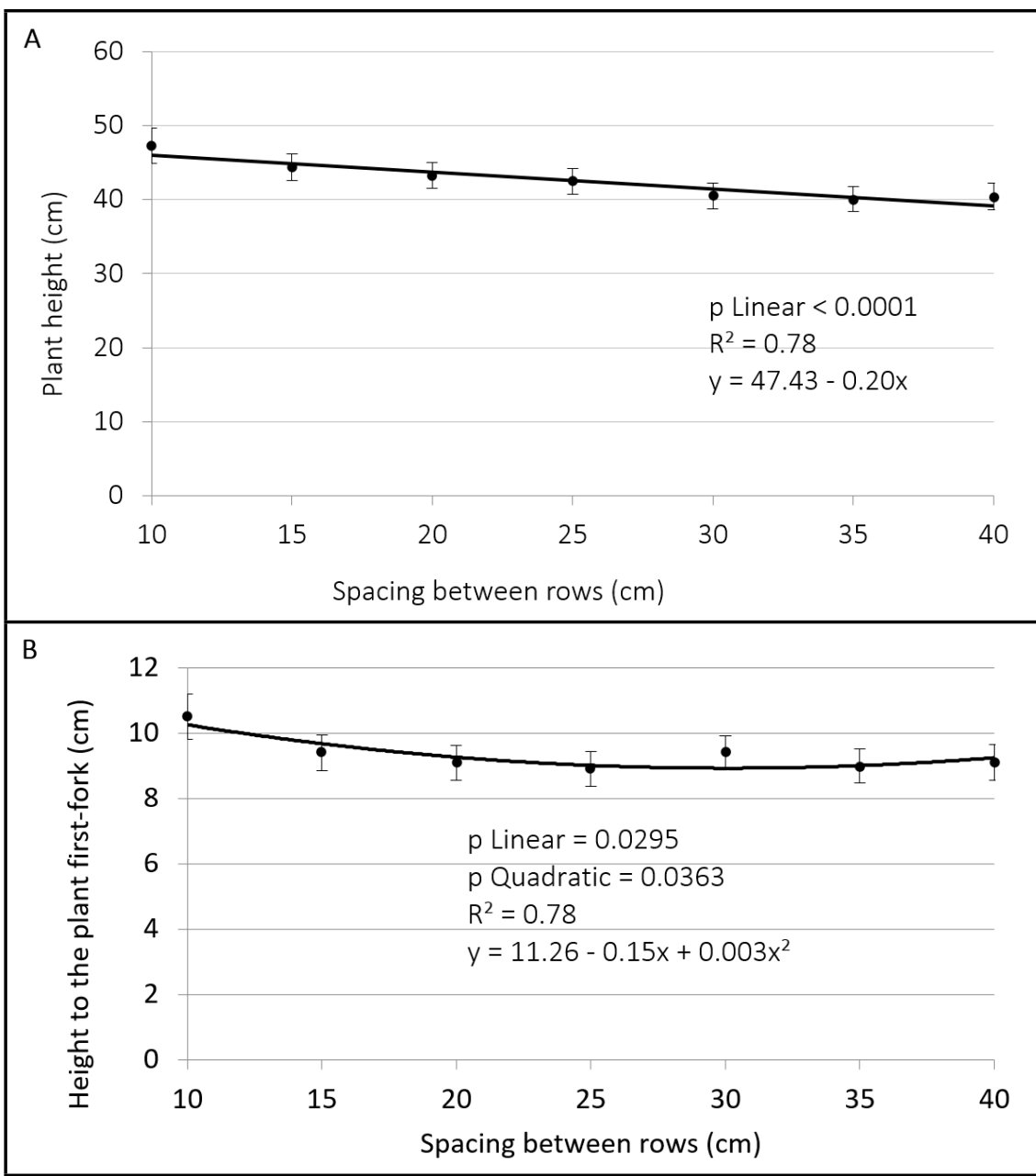

Figure 2. Plant height (A) and plant first bifurcation (B) of Jalapeño pepper cultivar BRS Sarakura in relation to in-row plant spacing (average of three years, 2015, 2016 and 2017). Brasília, Embrapa Hortaliças, 2019. show that plant density influences this trait inconsistently and subtly, showing a possibility to reduce spacing between plants with no loss of fruit mass. Probably, the most impacting influence is on the number of fruits per plant.

Average fruit length, another indicator of its size, was not influenced by spacing. Average value observed in this study was $10.0 \mathrm{~cm}$, ranging from 9.7 to $10.3 \mathrm{~cm}$. No spacing effect on fruit length was also verified by Paulus et al. (2015) for C. annuum and C. baccatum during the two experimental years.

Plant spacings evaluated in this study were based on studies which reported an increase in heights of plant and of plant first bifurcation as a result of reducing spacing between plants in planting row (Decoteau \& Graham, 1994; Paroissien \& Flynn, 2004), desirable effects for improving efficiency in mechanized harvest. In this study, plant height showed linear response, increasing according to a reduction of spacing between plants (Figure 2A). Paroissien \& Flynn (2004) also obtained an increase in $C$. annuиm height due to a population increase in all five conducted experiments. The authors evaluated populations from 51,000 to 493,400 plants ha ${ }^{-1}$ and obtained plant height between 53.6 and $92.3 \mathrm{~cm}$, considering that the highest value was obtained with the highest population density. Favela \& Sánchez (2003), evaluating different spacings, using two Jalapeño pepper cultivars, also found the highest average plant height $(72.3 \mathrm{~cm})$ in a denser spacing $(10 \mathrm{~cm}$ between plants in planting row, regardless spacing between rows). Similarly, Motsenbocker (1996) obtained a linear increase of C. annuum stem length in response to reduced plant spacing in the row (from 45 to $7.5 \mathrm{~cm}$ ), keeping the same row spacing $(85 \mathrm{~cm})$. That author noticed more prostrate plants at the largest spacing, which made mechanized harvest difficult (Motsenbocker, 1996).

The insertion of the lowest fruit, which also can be estimated by the stem first bifurcation height, where theoretically the lowest fruit is formed, was influenced in a quadratic form by the adopted spacing (Figure 2B). Paroissien \& Flynn (2004) obtained an 
increase in the first bifurcation height or the lowest fruit height as an increase of density of pepper plants (C. annuum) was provoked in all three experiments in which one or the other parameter was evaluated. The increase obtained by Paroissien \& Flynn (2004) was of, at least, $5 \mathrm{~cm}$ with population densities ranging from 51,000 to 341,500 plants $\mathrm{ha}^{-1}$. On the other hand, Russo (2008) did not obtain any significant effect on height of the first flower when varying spacing from 8 to $48 \mathrm{~cm}$ between plants and Kahn et al. (1997) did not observe any variation in the first bifurcation height with 5 to $25-\mathrm{cm}$ spacings between plants in a row.
In this study, variation of the first bifurcation height, verified in response to the studied spacings, was different in relation to plant height (Figure 2A), not responding clearly in a linear form to the variation in plant spacing in the row, although linear adjustment of the curve was also significant $(p<0.05$; Figure $2 \mathrm{~B})$. Considering the average values, bifurcation height was noticeably higher in the $10-\mathrm{cm}$ spacing between plants. It is possible that the lowest fruit production per plant in this spacing, in special, provides an increase in bifurcation height reducing the bending tendency of the main stem due to its fruit load, among other factors which were

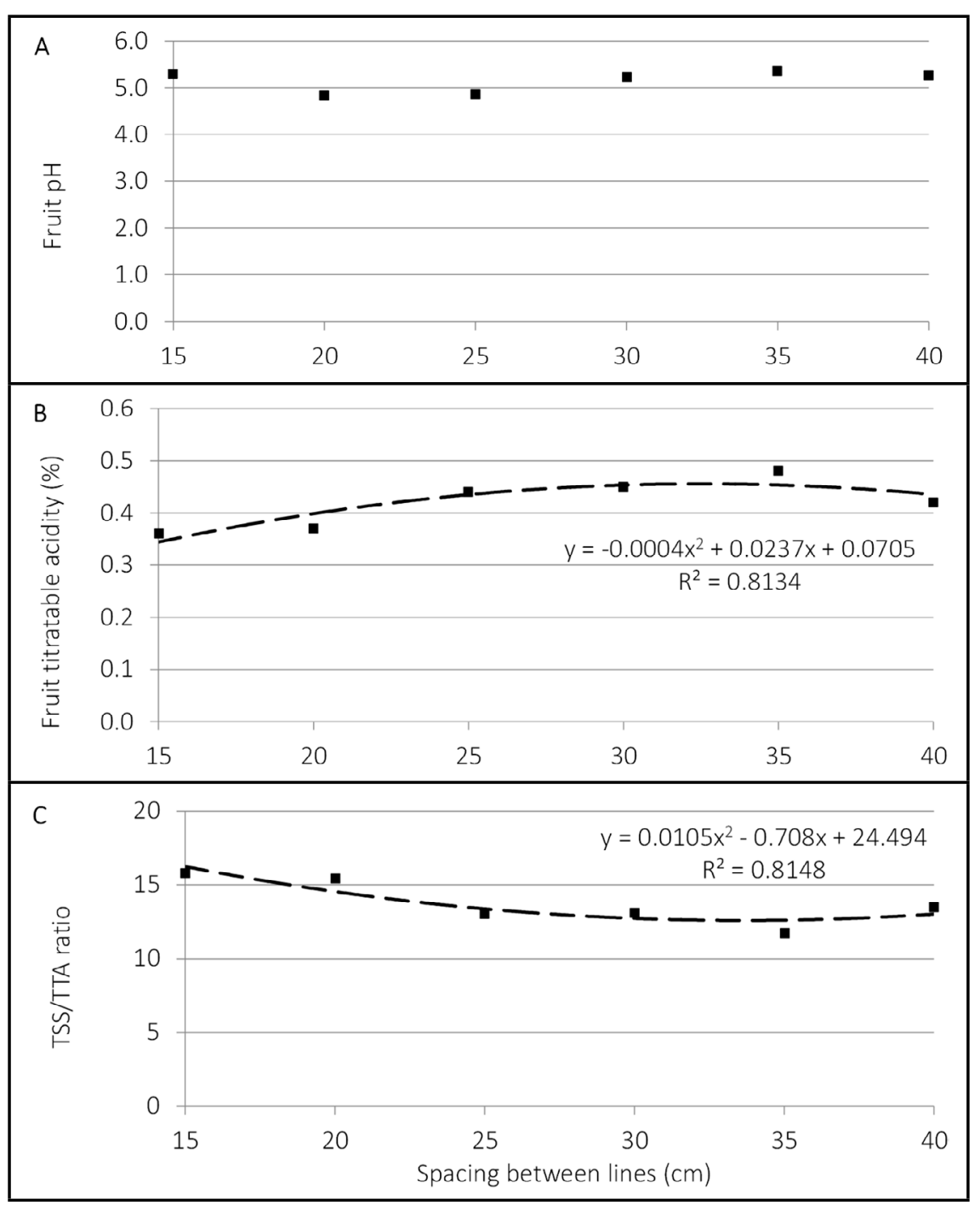

Figure 3. pH (A, regression adjustment was not significant), total titratable acidity (TTA) (B) and total soluble solids (TSS)/TTA ratio (C) of Jalapeño pepper cultivar BRS Sarakura in relation to in-row plant spacing. Significant quadratic regression (F, 5\%) for TTA and TSS/TTA ratio, coefficient of variation $4.25 \%, 10.33 \%$ and $11.97 \%$ for $\mathrm{pH}$, TTA and TSS/ TTA ratio, respectively. Brasília, Embrapa Hortaliças, 2019. not controlled in the experiment, such as wind and inclination of the seedling positioned during the transplant.

In order to evaluate the efficiency of mechanized harvest, Funk \& Walker (2010) studied four mechanized methods for harvesting Capsicum annuum var. annuum. The first method was using a stirring harvester with pepper fruit "combing". The second evaluated method was a harvester adapted with a mechanical agitation mechanism, aiming to reduce mechanical damages to fruits. And the third harvest mechanism was a cotton harvester with one platform adapted for pepper plant dimensions. Finally, the last studied harvester model was developed by New Mexico State University (2004). Harvest efficiency varied from 70 to $90 \%$, considering that the maximum loss of harvest accepted estimated by authors was $20 \%$. For all studied harvesters, height of the lowest fruits effectively harvested was $20 \mathrm{~cm}$. Thus, the authors highlighted that the percentage of fruits produced below $20 \mathrm{~cm}$ should not exceed $20 \%$, limit accepted for fruit loss at harvest.

In this study, the height of the highest first bifurcation was $10 \mathrm{~cm}$, obtained with the use of the smallest spacing between plants in the row (10 $\mathrm{cm})$. In this case, the use of mechanized harvester Etgar Moses 1010, the only model available in the producer region and, probably, the only model in Brazil, will be efficient only if the percentage of fruits produced between $10 \mathrm{~cm}$ (first bifurcation height in spacing 10 $\mathrm{cm}$ ) and $20 \mathrm{~cm}$ (minimum height for mechanized harvest) does not exceed $20 \%$ (Funk \& Walker, 2010). Thus, we verify the need to step up efforts to develop cultivars which respond more to cultural management and whose fruit production is concentrated above $20 \mathrm{~cm}$. Thus, breeding program of Capsicum from Embrapa Hortaliças aimed to select Jalapeño pepper genotypes with main plant and fruit traits which favor mechanized harvest using the machine Etgar Moses 1010 (Gomes et al., 2019).

Spacing in planting row influenced significantly $\mathrm{pH}$, TTA and TSS/TTA ratio (Figure 3). TSS content was not significantly influenced by variation in planting density, showing an average of 
$5.65 \%$ (measured in ${ }^{\circ} \mathrm{Brix}$ ) and variation coefficient of $8.37 \%$.

TTA values superior to $0.32 \%$ are considered suitable for tomato fruits intended for processing industry (Heine et al., 2015), reference presented in this discussion due to unavailability of reference data on pepper for industry. In this study, TTA values ranged from 0.36 to $0.48 \%$, which is to say, in all spacings, average of TTA was superior to the recommended value for industrial tomato (Figure 3B).

TSS/TTA ratio shows the balance between total soluble solid content and acid content in fruits. TSS/TTA ratio superior to 10 is recommended for industrial tomato (Heine et al., 2015). In this study, relation superior to 10 (Figure 3C) was obtained regardless the density used in planting row.

We noticed that $\mathrm{pH}$ presented little change (Figure 3A), ranging around 5.0. Although the effect of spacing on fruit $\mathrm{pH}$ was significant $(\mathrm{F}<5 \%)$, linear $\left(\mathrm{R}^{2}=\right.$ $0.16)$ and quadratic adjustment $\left(\mathrm{R}^{2}=\right.$ 0.39 ) were little accurate and because of that they were disregarded. This variable shows great importance for tomato processing industry (we believe, as well as for pepper) in order to produce sauce. As reference, $\mathrm{pH}$ in tomato fruits intend to industrial processing in Brazil, should be from 4.0 to 4.6, since the toxins released by the bacteria Clostridium botulinum are inhibited under this acidity level (Schwarz et al., 2013). In California, tomato processing industries use $\mathrm{pH}$ as a basic parameter to evaluate fruit quality a maximum $\mathrm{pH}$ of 4.4 being accepted (Anthon et al., 2011). The $\mathrm{pH}$ values obtained in this study were superior, unsuitable in all evaluated spacing considering the reference for tomato, though. The significant influence of spacing can be used as a strategy to obtain lower $\mathrm{pH}$, if this requirement is confirmed by the pepper sauce industry. This requires a clearer understanding of the effect of spacing on this parameter, though.

In studies on plant population density, a reduction in soluble solid content due to an increase in density is expected. This reduction is expected due to an increased leaf overlap and shading, which leads to a reduced plant photosynthetic rate (Paulus et al., 2015). With an increase in population density, the plant spends more energy on cell growth process rather than translocating sugars to fruits (Paulus et al., 2015). In this study, no deleterious influence of higher plant density neither on soluble solids content (variation between 5.55 and $5.79 \%$, measured in ${ }^{\circ}$ Brix) nor on other chemical traits of evaluated fruits was noticed. This fact allows an increase in number of plants ha ${ }^{-1}$ without impairing the industrial quality of "BRS Sarakura" fruits.

Evaluations in this study allow to recommend a smaller spacing comparing to the one used in Jalapeño pepper cultivation of cultivar BRS Sarakura in Ouvidor-GO, which is 30 $\mathrm{cm}$ between plants in row, obtaining a productivity gain without fruit quality loss. The highest evaluated density promoted an increase in height of "BRS Sarakura" (up to $6.9 \mathrm{~cm}$ ) compared to the conventional density adopted for this cultivar in that region. However, density effect on the first bifurcation height of "BRS Sarakura" plants was not significant.

Although higher plant density enables mechanized pepper harvest, it impacts on the production system. As an example: higher moisture between soil and plant canopy due to the increased evapotranspiration rate and lower air circulation can be noticed. This can lead to optimal conditions for some disease development, such as anthracnose, and pests, such as beetles, requiring greater control of phytosanitary crop treatments to avoid drop in productivity. On the other hand, the lowest proportion of exposed soil and incident solar radiation at the ground, due to the smaller spacing, reduces the weed incidence and, consequently, the number of weeding during the cycle (Embrapa, 2013).

Given the above, we highlight that (a) fruit productivity ha-1 ${ }^{-1}$ of the cultivar BRS Sarakura increased linearly with plant density up to the smallest evaluated spacing $(10 \mathrm{~cm}$ between plants); (b) fruit productivity per plant reduced linearly as spacing in planting rows became denser; (c) size and quality of fruits were not impaired by an increase in plant density; (d) reduction of spacing between plants in planting row provided a linear increase in plant height, influenced inconsistently the first bifurcation height, though; (e) planting density of 166,667 plants ha ${ }^{-1}$ provided the highest productivity per area among evaluated densities and (f) variation of stem first bifurcation height verified in this study may not be enough to enable mechanized harvest of cultivar BRS Sarakura.

\section{ACKNOWLEGMENTS}

The authors thank to Sakura Nakaya Alimentos Ltda. for financially supporting and to The National Council for Scientific and Technological Development $(\mathrm{CNPq})$ for scholarships and productivity grants.

\section{REFERENCES}

ABU, NE; ODO, CV. 2017. The effect of plant density on growth and yield of 'NsukkaYellow' aromatic pepper (Capsicum annuum L.). African Journal of Agricultural Research 12: 1269-1277. Doi: 10.5897/AJAR2016.11923.

AKINTOYE, HA; KINTOMO, AA; ADEKUNLE, AA. 2009. Yield and fruit quality of watermelon in response to plant population. International Journal of Vegetable Science 15: 369-380. Doi: 10.1080/19315260903012110.

AMINIFARD, MH; AROIEE, H; KARIMPOUR, S; NEMATI, H. 2010. Growth and yield characteristics of paprika pepper (Capsicum annuum L.) in response to plant density. Asian Journal of Plant Sciences 9: 276-280.

ANTHON, GE; STRANGE, M; BARRETT, DM. 2011. Changes in $\mathrm{pH}$, acids, sugars and other quality parameters during extended vine holding of ripe processing tomatoes. Journal of the Science of Food and Agriculture 91: 1175-1181.

CAVERO, J. 2001. Plant density affects yield, yield components, and color of direct-seeded paprika pepper. HortScience 36: 76-79.

DECOTEAU, DR; GRAHAM, AH. 1994. Plant spatial arrangement affects growth, yield, and pod distribution of cayenne peppers. HortScience 29: 149-151.

DE WITT, D; BOSLAND, PW. 2009. The complete Chile pepper book: a gardener's guide to choosing, growing, preserving and cooking. London, UK: Timber Press. 336p.

EMBRAPA. 2013. Desafios, Avanços e Soluções no Manejo de Plantas Daninhas. Brasilia: Embrapa. 152p.

EMBRAPA. 2014. Visão 2014-2034: o futuro do desenvolvimento tecnológico da agricultura 
brasileira. Brasília: Embrapa. 194 p.

EMBRAPA. 2015. Contrato de parceria em pesquisa e desenvolvimento agropecuários $(P \& D)$ entre Sakura-Nakaya alimentos LTDA, Embrapa e FAPED (Embrapa código 10200.15/0001-8). Brasília: Embrapa, 24p.

FAVELA, ML; SÁNCHEZ, NC. 2003. El arreglo topológico y su efecto en el crecimiento, desarrollo y producción del chile jalapeño (Capsicum annuum L.). Revista Fitotecnia Mexicana 26: 81-87.

FUNK, PA; WALKER, SJ. 2009. Green chile pepper harvest mechanization. Saint Joseph, USA: The American Society of Agricultural and Biological Engineers. 14p.

FUNK, PA; WALKER, SJ. 2010. Evaluation of five green chile cultivars utilizing five different harvest mechanisms. American Society of Agricultural and Biological Engineers 26: 955-964. Doi: 10.13031/2013.35906.

GOMES, LM; RIBEIRO, CSC; RAGASSI, CF; SILVA, LS; REIFSCHNEIDER, FJB. 2019. Advanced lines of Jalapeño pepper with potential for mechanical harvesting. Ciência Rural 49: e20180222. Doi: 10.1590/0103$8478 \mathrm{cr} 20180222$.

HEINE, AJM; MORAES, MOB; PORTO, JS; SOUZA, JR; REBOUÇAS, TNH; SANTOS, BSR. 2015. Número de hastes e espaçamento na produção e qualidade do tomate. Scientia Plena 11: 1-7. Doi: 10.14808/ sci.plena.2015.090202.

KAHN, BA; COOKSEY, JR; MOTES, JE. 1997. Within-row spacing effects on traits of importance to mechanical harvest in paprikatype peppers. Scientia Horticulturae 69: 31-39.
Doi: 10.1016/S0304-4238(96)00981-8. MATTOS, LM; MORETTI, CL; HENZ, GP. 2007. Protocolos de avaliação da qualidade química e fisica de pimentas (Capsicum spp.). Brasília, BR: Embrapa Hortaliças. 9p.

MOORE, KJ; DIXON, PM. 2015. Analysis of combined experiments revisited. Agronomy Journal 107: 763-771.

MOTSENBOCKER, CE. 1996. In-row plant spacing affects growth and yield of pepperoncini pepper. HortScience 31: 198200.

NEW MEXICO STATE UNIVERSITY. 2004. Chile Machine Harvesting: Observations 2004. Available at: https://nmsu.libguides. com/c.php?g=206372\&p=4345683. Accessed December 13, 2018.

ONOYAMA, SS;ANJOS, UG; REIFSCHNEIDER, FJB; MELO, WF; VALE, LSR; RIBEIRO, RG; OLIVEIRA, EJS. 2011. Coletando, conservando e utilizando a biodiversidade de pimentas em Goiás: agregando conhecimento e valor do bioma à agroindústria. Atelie Geográfico 5: 106-122.

PAROISSIEN, M; FLYNN, R. 2004. Plant spacing/plant population for machine harvest (New Mexico State University Chile Task Force Report 13). LasCruces, USA: New Mexico State University. 20p.

PAULUS, D; VALMORBIDA, R; SANTIN, A; TOFFOLI, E; PAULUS, E. 2015. Crescimento, produção e qualidade de frutos de pimenta (Capsicum annuum) em diferentes espaçamentos. Horticultura Brasileira 33: 91-100. Doi 10.1590/S0102053620150000100015.
REIFSCHNEIDER, FJB; LOPES, CA; RIBEIRO, CSC. 2016. Continuity, focus and impact: a commented historical perspective on Embrapa Vegetables' extended Capsicum breeding program. Horticultura Brasileira 34: 155-160. Doi: 10.1590/S0102-053620160000200002.

RIBEIRO, CSC. 2008. Pimentas Capsicum. Brasília: Embrapa. 200p.

RUSSO, VM. 2008. Yield in non-pungent Jalapeño pepper established at different in-row spacings. HortScience 43: 2018-2021.

SAS INSTITUTE. 2012. SAS OnDemand for Academics Release 9.04.01M5P09132017. SAS Institute Inc. Available at: https://odamid. oda.sas.com/SASStudio. Accessed February 11, 2019.

SCHWARZ, K; RESENDE, JTV; PRECZENHAK, AP; PAULA, JT; FARIA, MV; DIAS, DM. 2013. Desempenho agronômico e qualidade físico-química de híbridos de tomateiro em cultivo rasteiro. Horticultura Brasileira 31: 410-418. Doi: 10.1590/S010205362013000300011.

UCHANSKI, ME; BLALOCK, A. 2013. Ethephon improved pigmentation but had no effect on cayenne pepper fruit yield in southern New Mexico. HortScience 48: 738-741.

WALKER, SJ; FUNK, PA. 2014. Mechanizing chile peppers: challenges and advances in transitioning harvest of New Mexico's signature crop. HortTechnology 24: 281-284.

WALL, MM; WALKER, S; WALL, AD; HUGHS, E; PHILLIPS, R. 2003. Yield and quality of machine-harvested red chile peppers. HortTechnology 13: 296-302. 